\title{
ANALISIS HABITS OF THINKING INTERDEPENDENTLY (HTI) SISWA SMP DALAM PEMBELAJARAN KOOPERATIF
}

\author{
Ummul Huda \\ Fakultas Tarbiyah dan Ilmu Keguruan, Jurusan Tadris Matematika IAIN Batusangkar \\ Korespondensi: Jln. Sudirman No. 137 Kubu Rajo Lima Kaum Batusangkar \\ e-mail: huda.ummul@gmail.com
}

\begin{abstract}
This research is motivated by the lack of social interaction among students to improve the quality of understanding and learning. Yet this is very important to achieve maximum results in learning, including the habit of students to give feedback, criticism, responses, compliments to each other; mutual energies and thoughts to the group; more concerned with common interests rather than personal interests; mutual aid among fellow members of the group to ensure that all members understand the task they are doing; and they not only contribute but also learn something from the group. Therefore, this study discusses about how the image of students HTI in learning math is done cooperatively. The method used is descriptive quantitative research, the subjects are students of SMPN 5 Bandung totaling 29 person. The instrument that this research used was a questionnaire and observation sheet. The result of this research show that students' HTI in learning cooperative are good, such as they are carelemphathize to the others feeling and thought, to look at and listen to others with understanding and empathy, showing their independence in learning and collaborative team.
\end{abstract}

Kata Kunci: Habit of Thinking Interdependently (HTI), Pembelajaran Kooperatif

\section{PENDAHULUAN}

$O$ etiap individu memiliki kebiasaan hidup yang dapat mengarah pada hal yang positif maupun negatif bergantung pada pemikiran, lingkungan dan pribadi yang membentuknya. Kebiasaan atau habit dalam kamus bahasa Inggris diartikan sebagai "something you do regularly, almost without thinking about it." Kebiasaan merupakan sesuatu yang dilakukan secara teratur, yang dalam melakukannya hampir tidak memikirkan apa-apa, atau mengalir begitu saja. Konsep ini menunjukkan bahwa suatu kegiatan yang telah menjadi kebiasaan dapat dengan mudah dilakukan secara berulang-ulang, karena tidak memerlukan aktivitas kognitif yang sukar. Russel (Costa, 2012) mengatakan bahwa sebagian besar pengetahuan kita adalah kebiasaan. Kebiasaan dapat dibentuk melalui proses pembelajaran. Oleh karena itu, tujuan pembelajaran hendaknya mampu membangun kebiasaan siswa untuk berpikir.

Kebiasaan berpikir merupakan salah satu kebiasaan yang mempengaruhi proses perkembangan individu. Kebiasaan berpikir dipandang penting saat proses pembelajaran karena dapat membantu siswa menyelesaikan berbagai permasalahan yang muncul dalam kehidupan sehari-hari. Untuk menyelesaikan berbagai macam permasalahan tersebut individu sebagai makhluk sosial juga 
membutuhkan bantuan dari orang lain, ibarat pepatah Minangkabau mengatakan "duduak surang basampik-sampik, duduak basamo balapang-lapang", yang berarti apabila suatu pekerjaan dikerjakan sendiri akan terasa lebih berat dibandingkan bila dikerjakan secara bersama-sama. Pemikiran beberapa orang akan lebih bagus daripada sendiri. Jadi, peningkatan kemampuan berpikir siswa dapat ditopang dengan pembelajaran secara bersama-sama atau kelompok.

Siswa adalah makhluk sosial yang saling membutuhkan satu sama lain demi kelangsungan hidupnya. Sebagai makhluk sosial siswa juga bergantung dan perlu bekerjasama dengan orang lain dalam pemahaman pembelajarannya. Informasi atau gagasan tidak hanya muncul dari satu siswa kepada teman lainnya, melainkan setiap siswa dalam kelompok hendaknya memberikan kontribusi yang seimbang terhadap kemajuan kelompok dalam menyelesaikan masalah. Bekerja dalam kelompok membutuhkan kemampuan untuk menguji kelayakan/kebenaran ide, solusi dan strategi pada orang lain, membutuhkan pengembangan kemauan dan keterbukaan untuk menerima umpan balik dari teman secara kritis (Costa, 2012). Kerjasama dan belajar dari orang lain dalam situasi timbal balik seperti ini dinamakan dengan habit of thinking interdependently (HTI).

HTI merupakan salah satu dari 16 macam kebiasaan berpikir (habit of mind) yang diperkenalkan oleh Costa \& Kallick pada tahun 2000. Interdependent berarti suatu kondisi yang saling tergantung antara individu dengan orang lain dalam membina suatu kerjasama atau hubungan. Menurut Sumarmo (2013) interdependen-ce adalah rasa ketergantungan berpikir, melukiskan individu sebagai anggota kelompok yang saling bergantung, menunjukkan kekitaan selain keakuannya, mengambil peran sebagai bagian dari keseluruhan, berpandangan bahwa keseluruhan lebih efisien daripada individu masing-masing, dan menginterpretasikan konflik sebagai sesuatu yang berguna dalam mencari solusi masalah, pendekatan baru atau alternatif solusi lainnya. Sedangkan HTI adalah kebiasaan berpikir bersamasama dengan orang lain, untuk dapat lebih saling tergantung dan sensitif akan kebutuhan orang lain (Costa, 2012). Costa juga menjelaskan bahwa HTI memberikan kesempatan kepada siswa untuk saling bertukar pikiran, akan tetapi siswa mengantisipasi agar pemikirannya berbeda dengan orang lain. Hal ini nantinya memacu mereka kreatif untuk mencari alternatif solusi yang sekiranya berbeda dengan yang diperoleh oleh teman-temannya.

Costa \& Kallick $(2000,2012)$ kebiasaan berpikir bersama-sama dengan orang lain merupakan salah satu keterampilan yang paling penting untuk dimiliki siswa. Kerjasama dalam kelompok mengindikasikan setiap anggota untuk saling memberi dan saling menerima. Siswa saling memberikan kontribusi berupa kritikan, pujian, tanggapan, saran, penguatan yang membangun, saling membantu teman yang mengalami kesusahan, mengambil pelajaran dari kelompok dan sebagainya. Kemudian Costa (2012) mengatakan "working in goups requires the ability to justify ideas and to test the flexibility of solution strategies on others. It also requires developing a willingness and an openness to accept feedback from a critical friend. Through this interaction, the group and the individual continue to grow." Bekerja dalam kelompok membutuhkan kemampuan untuk membenarkan ide dan menguji kelayakan solusi dari strategi yang digunakan pada orang lain, membutuhkan pengembangan kemauan dan keterbukaan untuk menerima umpan balik dari teman secara kritis.

Interaksi siswa dalam kelompok menurut Costa (2012) dan Sumarmo 
(2013) dapat berupa saling memberikan masukan, kritikan, tanggapan, pujian; saling mencurahkan tenaga dan pikiran untuk kelompok; lebih mementingkan kepentingan bersama daripada kepentingan pribadi; saling membantu antar sesama anggota kelompok dengan memastikan bahwa seluruh anggota paham terhadap tugas yang mereka kerjakan; dan mereka tidak hanya berkontribusi tetapi juga belajar sesuatu dari kelompok. HTI berkembang ketika siswa mampu membangun hubungan yang baik, langgeng, kuat dan produktif antar sesama anggota kelompok. Menurut BBSS (2008) hubungan yang terjalin dalam kelompok dapat diukur dengan memperhatikan: (a) kepedulian/berempati terhadap perasaan dan pikiran orang lain, (b) berupaya melihat dan mendengarkan orang lain dengan pemahaman dan empati, (c) menunjukkan kemandirian dalam belajar dan melihat sukacita dalam pembelajaran, dan (d) tim/pekerja yang kolaboratif.

Kolaborasi siswa secara bersamasama lebih kuat dari segi intelektual maupun fisik daripada bekerja sendiri, dan tidak ada seseorang yang dapat menghasilkan alternatif jawaban sebanyak beberapa orang (Costa, 2012). Kolaborasi hasil pemikiran siswa memungkinkan lebih banyak ide atau gagasan yang akan muncul, sehingga dapat membuka cakrawala kreativitas berpikir siswa. Jadi, peningkatan kemampuan berpikir kreatif matematis siswa dapat ditopang dengan pembelajaran secara berkelompok atau kooperatif.

Pembelajaran kooperatif dilaksanakan dalam kelompok kecil dengan tingkat kemampuan matematis siswa yang heterogen, siswa bekerja sebagai sebuah tim dalam memecahkan masalah dan menyelesaikan tugas kelompok untuk mencapai tujuan bersama. Setiap siswa memiliki kepentingan dan tujuan yang sama, yaitu untuk meningkatkan kemampuan dan kualitas kelompok dalam memecahkan masalah. Kelebihan pembelajaran kooperatif menurut Suherman (2003) ialah mampu melatih siswa untuk mendengarkan pendapatpendapat orang lain dan merangkumnya; melatih kerjasama, saling membantu satu sama lain dalam mengintegrasikan pengetahuan baru dan pengetahuan yang telah dimilikinya; meningkatkan sikap positif siswa; membangun kepercayaan diri dalam menyelesaikan masalah; mengurangi bahkan menghilangkan rasa cemas terhadap matematika (math anxiety); dan bermanfaat bagi siswa yang heterogen. Kemudian hasil penelitian Kristiawan (2013) mengungkapkan bahwa banyak kelebihan dari pembelajaran kooperatif, salah satunya adalah siswa lebih aktif di kelas.

Berdasarkan uraian di atas, kebiasaan berpikir siswa bersama-sama dengan orang lain merupakan hal yang penting untuk peningkatan kualitas pembelajaran. Untuk itu, perlu dilakukan analisis terhadap HTI siswa dalam pembelajaran kooperatif.

\section{METODOLOGI}

Metode yang digunakan dalam penelitian ini adalah deskriptif kuantitatif. Adupun yang menjadi subjek penelitian adalah siswa SMP Negeri 5 Bandung yang berjumlah 29 orang, terdiri dari 16 siswa laki-laki dan 13 siswa perempuan.

Instrumen yang digunakan berupa angket dan lembar observasi yang sebelumnya telah divalidasi peleh beberapa orang pakar. Lembar observasi digunakan untuk melihat aktivitas guru dan siswa dalam pembelajaran matematika yang kooperatif. Angket digunakan untuk kecenderungan kebiasaan berpikir yang dilakukan siswa saat pembelajaran. Angket diolah dengan skala Likert dengan skor 1-4. Data diolah secara deskriptif, dengan melihat 
kecenderungan pilihan siswa dari setiap item pernyataan, positif atau negatif. Data hasil observasi dijadikan sebagai pertimbangan terhadap hasil angket agar data dari semua sumber mengarah pada simpulan yang sama sehingga kesimpulan yang diambil lebih kuat.

\section{HASIL PENELITIAN DAN PEM- BAHASAN}

Angket digunakan untuk mengetahui kebiasaan berpikir saling bergantung antara siswa dalam kelompok belajarnya. Angket terdiri atas empat indikator dengan 30 item pernyataan. Jawaban siswa untuk masing-masing pernyataan diberi skor (1-4). Distribusi total data angket skala HTI disajikan pada tabel berikut.

Tabel 1. Distribusi Total Data Angket Skala HTI

\begin{tabular}{cccccccccc}
\hline \multirow{3}{*}{ Indikator } & \multicolumn{10}{c}{ Skor } \\
\cline { 2 - 10 } & \multicolumn{2}{c}{4} & $\%$ & $\mathrm{f}$ & $\%$ & $\mathrm{f}$ & $\%$ & $\mathrm{f}$ & $\%$ \\
\cline { 2 - 9 } & $\mathrm{f}$ & $\%, 94$ & 448 & 51,50 & 246 & 28,28 & 46 & 5,29 \\
\hline Berpikir saling bergantung & 130 & 14,94
\end{tabular}

Tabel di atas menunjukkan bahwa secara umum siswa yang melakukan pembelajaran kooperatif menunjukkan kebiasaan sering berpikir saling bergantung sebesar $66,44 \%$, sedangkan sis- wa yang jarang menunjukkan kebiasaan ini sebesar 33,57\%.

Adapun distribusi berdasarkan indikator secara lengkap meliputi frekuensi, persentase responden, dan skor pernyataan dijabarkan pada tabel berikut.

Tabel 2. Distribusi Data Angket Skala HTI per Indikator

\begin{tabular}{|c|c|c|c|c|c|c|c|c|}
\hline \multirow{3}{*}{ Indikator } & \multicolumn{8}{|c|}{ Skor } \\
\hline & \multicolumn{2}{|r|}{4} & \multicolumn{2}{|c|}{3} & \multicolumn{2}{|r|}{2} & \multicolumn{2}{|c|}{1} \\
\hline & $\mathrm{f}$ & $\%$ & $\mathrm{f}$ & $\%$ & $\mathrm{f}$ & $\%$ & $\mathrm{f}$ & $\%$ \\
\hline $\begin{array}{l}\text { Memiliki kepedulian/ } \\
\text { berempati terhadap perasaan } \\
\text { dan pikiran orang lain }\end{array}$ & 52 & 25,62 & 98 & 48,28 & 47 & 23,15 & 6 & 2,96 \\
\hline $\begin{array}{l}\text { Berupaya melihat dan } \\
\text { mendengarkan orang lain } \\
\text { dengan pemahaman dan empati }\end{array}$ & 34 & 19,54 & 99 & 56,90 & 31 & 17,82 & 10 & 5,75 \\
\hline $\begin{array}{l}\text { Menunjukkan kemandirian } \\
\text { dalam belajar dan melihat suka } \\
\text { cita dalam pembelajaran }\end{array}$ & 20 & 7,66 & 121 & 46,36 & 98 & 37,55 & 22 & 8,43 \\
\hline Tim/pekerja yang kolaboratif & 24 & 10,34 & 130 & 56,03 & 70 & 30,17 & 8 & 3,45 \\
\hline
\end{tabular}

Tabel di atas menunjukkan bahwa kebiasaan dengan persentase terbesar yang dimiliki siswa adalah berupaya melihat dan mendengarkan orang lain dengan pemahaman dan empati sekitar $76,44 \%$, sedangkan kebiasaan yang paling jarang ditunjukkan siswa adalah kemandirian dalam belajar dan melihat suka cita dalam pembelajaran, yaitu sebesar $45,98 \%$.

HTI berkaitan dengan kebiasaan berpikir siswa yang saling bergantung dalam menyelesaikan masalah pada kelompoknya. Sebagian besar siswa yang melakukan pembelajaran kooperatif menunjukkan kebiasaan berpikir saling 
bergantung, baik pada aspek memiliki kepedulian terhadap perasaan dan pikiran orang lain, berupaya melihat dan mendengarkan orang lain dengan pemahaman dan empati, menunjukkan kemandirian dalam belajar dan melihat suka cita dalam pembelajaran, serta tim/pekerja yang kolaboratif.

Siswa menunjukkan kebiasaan sering memiliki kepedulian/berempati terhadap perasaan dan pikiran orang lain. Akan tetapi pada aspek menghadapi situasi secara bijak, siswa jarang menunjukkannya. Masih banyak siswa yang tidak mampu mengambil keputusan sebagaimana mestinya. Siswa jarang menunjukkan kebiasaan sopan dan perhatian terhadap orang lain. Hal ini terlihat dari kebiasaan siswa yang membiarkan temannya yang tidak mau terlibat dalam menyelesaikan masalah kelompok, mereka tidak menegur dan mengajak temannya untuk bekerjasama. Selanjutnya, siswa cukup berempati dan peka terhadap kebutuhan orang lain, mereka membantu teman yang mengalami kesulitan. Akan tetapi, cara yang digunakan siswa kurang tepat, mereka bukan memberikan pemahaman kepada temannya melainkan lebih kepada memberikan kunci jawaban. Akibatnya siswa hanya mampu menyelesaikan masalah tetapi belum memahaminya dengan baik.

Siswa cukup sering menunjukkan kebiasaan berupaya melihat dan mendengarkan orang lain dengan pemahaman dan empati. Akan tetapi pada aspek mengatur keimpulsivan, siswa sering ceroboh dan tergesa-gesa dalam meng-ambil keputusan, kadang-kadang siswa berbuat secara tiba-tiba tanpa pertimbangan. Berdasarkan hasil pengamatan peneliti siswa terlihat tergesagesa dan ingin segera cepat selesai, tidak berhati-hati dalam membaca dan menyelesaikan masalah. Jika tugasnya telah selesai kebanyakan dari siswa jarang memeriksa kembali hasil pekerjaannya. Siswa sering menerima kritikan yang disampaikan teman tanpa menyelelidikinya terlebih dahulu. Peneliti mendapati ada siswa yang memperoleh contekan jawaban dari temannya, kemudian serta merta mereka langsung menghapus jawaban semula dan menggantinya sesuai dengan informasi yang diperoleh dari teman. Setelah diperiksa ternyata jawabannya salah, jawaban yang benar adalah jawaban yang pertama kali mereka berikan.

Temuan lain, penyelesaian tugas kelompok tidak selalu merupakan hasil kesepakatan semua anggota, kadangkadang hanya hasil pemikiran dari beberapa orang anggota yang aktif. Akibatnya siswa akan mengambil kebijakan sendiri terhadap keputusan kelompok tanpa mendiskusikannya terlebih dahulu. Siswa pintar lebih banyak mendominasi dalam penyelesaian tugas kelompok. Hal ini disebabkan karena dalam pembelajaran yang dilaksanakan di kelas siswa langsung dikondisikan untuk berkelompok dalam memahami masalah yang diberikan, siswa tidak diberikan waktu terlebih dahulu untuk menelaah tugas secara individu. Artinya, hanya siswa yang memiliki pengetahuan awal bagus yang mampu memahami dan menyelesaikan tugas yang diberikan dengan baik.

Secara umum siswa jarang menunjukkan kemandirian dalam belajar dan melihat suka cita dalam pembelajaran. Hal ini terlihat dari kebiasaan siswa dalam mengembangkan keyakinan terhadap tugas dan situasi yang sulit, siswa jarang merasa yakin akan kemampuannya dalam menyelesaikan tugas yang diberikan dan melewati semua kesulitan yang ada. Siswa memiliki motivasi yang rendah terhadap pembelajarannya. Siswa masih membutuhkan penghargaan dan pujian untuk mendongkrak motivasinya. Hal ini terlihat dari kebiasaan siswa yang setiap kali diberikan tugas selalu menanyakan "Apakah nilainya masuk lapor atau 
masuk buku niai?" kalau sekiranya nilai dari tugas tersebut diperhitungkan barulah siswa semangat untuk mengerjakan tugas.

Selain itu, saat pembelajaran guru biasanya meminta siswa untuk mengerjakan soal di papan tulis. Kebanyakan siswa enggan dan tidak mau diminta menyelesaikan soal. Saat ditanyakan apa penyebabnya mereka menjawab bahwa "sebenarnya saya bisa Bu tapi malas aja." Akhirnya muncul ide guru untuk mencatat nama-nama siswa yang aktif yang mau ke depan kelas menyelesaikan soal. Di luar dugaan, ternyata siswasiswa berebut untuk berpartisipasi. Terlihat bahwa keaktifan dan motivasi siswa muncul saat dihubungkan dengan nilai. Hal ini menegaskan bahwa siswa lebih mementingkan nilai daripada makna dan manfaat dari ilmu itu sendiri. Padahal, dalam kurikulum telah disebutkan bahwa semua tindak tanduk siswa menjadi bahan penilaian bagi guru, baik itu aspek kognitif, afektif maupun psikomotor. Tujuan pendidikan tidak hanya mengharapkan siswa pintar di bidang ilmu pengetahuan, akan tetapi harus memiliki keahlian dan perilaku yang baik. Dengan kata lain, kesadaran siswa akan pentingnya pembelajaran matematika masih rendah.

Siswa kurang menikmati pembelajaran secara mandiri, karena tidak semua siswa menunjukkan reaksi antusias dan rasa ingin tahu yang tinggi terhadap segala sesuatu yang terjadi dalam pembelajarannya. Siswa masih mengandalkan temannya untuk menjelaskan materi bangun ruang sisi datar apabila mereka mengalami kesulitan tanpa berusaha terlebih dahulu. Siswa kurang tertantang dalam menyelesaikan soal yang sulit. Jika diberikan soal yang bersifat non rutin dan terbuka, semangat dan motivasi untuk mengerjakannya rendah sekali terutama pada siswa perempuan, mereka menyerah dan merasa putus asa tanpa terlebih dahulu mengidentifikasi masalah beserta penyelesaiannya. Siswa kurang menunjukkan keaktifan dalam pembelajarannya. Hal ini tergambar saat guru melontarkan beberapa pertanyaan, siswa jarang merespon dan menjawabnya. Hal ini disebabkan karena siswa kurang terbiasa dengan pendekatan pembelajaran yang menuntut keaktifannya (student centre). Siswa terbiasa dengan pembelajaran yang berpusat kepada guru (teacher centre). Guru menjadi penentu dalam pembelajaran dan kebanyakan informasi pembelajaran diberikan oleh guru, sedangkan siswa lebih banyak pasif. Semua kegiatan pembelajaran seakan-akan didiktekan oleh guru kepada siswa, sehingga siswa tidak dibiasakan untuk berpikir di luar jalur yang biasa mereka tempuh dalam pembelajaran, dengan kata lain pemunculan kreativitas siswa kurang difasilitasi.

Secara umum, siswa cukup sering menunjukkan kebiasaan sebagai tim atau pekerja yang kolaboratif. Hal ini tergambar dari kebiasaan siswa memberikan kesempatan kepada orang lain untuk menyampaikan pandangan dan pendapatnya. Siswa tidak memaksakan pendapat atau kehendaknya, dan menghargai hak semua anggota. Mereka menyadari bahwa setiap anggota memiliki hak dan kewajiban yang sama untuk meningkatkan kualitas kelompok. Akan tetapi mereka kurang kompak dalam pembelajaran, misalnya saat mencari berbagai alternatif solusi dari masalah yang diberikan.

Siswa kurang mampu untuk fleksibel dan meneliti masalah dari sudut pandang yang berbeda, mereka cukup puas dan berbangga hati jika telah menemukan suatu jawaban atas masalah yang dipecahkan, seharusnya anggotaanggota dalam kelompok mampu menghasilkan berbagai jawaban atau cara jawab dari berbagai masalah yang dihadapi. Hal ini disebabkan karena siswa tidak terbiasa menghadapi masalah terbuka yang menuntut mereka mampu 
menemukan dan memikirkan berbagai penyelesaian masalah secara kreatif. Namun, lama kelamaan hal ini bisa diantisipasi dengan cara membiasakan mereka untuk menemukan minimal dua jawaban yang berbeda dari setiap permasalahan yang diberikan. Beberapa siswa juga mampu memberikan jawaban di luar prediksi peneliti. Siswa menunjukkan kebiasaan yang cukup baik pada aspek mengkomunikasikan ide dengan jelas dan berkomunikasi baik dengan orang lain. Saat diskusi, siswa menyampaikan idenya dengan jelas dan teman-teman cukup mengerti dengan apa yang disampaikan, begitu juga saat persentasi di depan kelas. Walaupun saat pelaksanaan persentasi masih ada siswa yang merasa gugup, canggung dan kesulitan dalam menjelaskan hasil pekerjaan kelompoknya, tetapi mereka cukup berani untuk mencoba mengungkapkan hasil pemikirannya kepada teman-teman di kelas.

\section{DAFTAR RUJUKAN}

Aguspinal, 2011. Peningkatan kemampuan berpikir kreatif dan komunikasi matematis siswa SMA melalui pen-dekatan open-ended dengan strategi group-to-group. Tesis. Tidak dipublikasikan. SPS UPI.

BBSS. (2008). Habits of Mind: Thinking Interdependently. Tahoma School District.

Costa, L \& Bena Kallick. (2012). Belajar dan Memimpin dengan Kebiasaan Pikiran: 16 Karakteristik Penting Untuk Sukses. Jakarta: Indeks

Kristiawan, M. (2013). The Implementation of Cooperative Learning in English Class of Favorite School of Secondary High School
Ditemukan juga bahwa sebagian besar siswa lebih senang belajar sendiri dibandingkan dengan berdiskusi dalam kelompoknya, hal ini lebih banyak ditunjukkan oleh siswa berkemampuan tinggi. Sebagaimana yang dikatakan Wiyanto (2008) bahwa siswa yang memiliki kemampuan kognitif tinggi cenderung memiliki sikap bekerjasama yang relatif rendah dibandingkan siswa yang memiliki kemampuan rata-rata atau di bawah rata-rata.

\section{PENUTUP}

Siswa menunjukkan HTI dalam pembelajaran kooperatif, baik kepedulian/berempati terhadap perasaan dan pikiran orang lain, berupaya melihat dan mendengarkan orang lain dengan pemahaman dan empati, menunjukkan kemandirian yang cukup dalam belajar dan melihat sukacita pembelajaran serta tim/pekerja yang cukup kolaboratif.

5 Batusangkar, West Sumatera. Academic Journals, 5(6), 85-90.

Lim, K. (2013). General and Mathematical Habits of Mind: An Overview. San Diego: University of Texas at El Paso

Mahmudi, A dan Utari Sumarmo. (2011). Pengaruh satrategi mathematical habits of mind (MHM) berbasis masalah terhadap kreativitas siswa. Makalah. Cakrawala Pendidikan.

Rosita, N.T. (2012). Pembelajaran Matematika dengan Pendekatan Open-Ended dalam Meningkatkan Kemampuan Berpikir Kreatif Matematis Siswa. Tesis: Tidak Dipublikasikan 
Suherman, E dkk. (2003). Strategi Pembelajaran Matematika Kontemporer. Bandung: JICA

Sumarmo, U. (2013). Berpikir dan Disposisi Matematika serta

Pembelajarannya. Bandung: Universitas Pendidikan Indonesia

Wiyanto, dkk. (2008). Menyiapkan Guru Sains Mengembangkan Kompetensi Laboratorium. Semarang: UNNES Press. 